\title{
Research on Accounting Talents Training Mode under the Background of Informatization
}

\author{
Hu Jing \\ Yiwu Industrial \& Commercial College, Yiwu, Zhejiang, 322000
}

Keywords: informatization; ERP; accounting; talent

\begin{abstract}
With the development and application of information technology such as computers and networks, people's production and life have undergone earth-shaking changes, and various fields are deeply affected by information technology. Especially the accounting industry is closely related to information processing. Under the background of informatization, the methods, modes, and contents of accounting work have undergone qualitative changes. This requires to meet the actual needs of accounting talents in the information age, and adjust and optimize the current talent training model in light of the problems existing in the current accounting talent training.
\end{abstract}

\section{Introduction}

In the context of informatization, accounting work focuses on the input and output functions of information. Redundant and complex information is processed and clearly expressed through scientific methods, which provides a powerful reference for managers' economic decision-making. This requires accountants not only to have excellent basic accounting skills and extensive management knowledge, but also to have good professional judgment, information analysis and language and writing skills to deal with the impact of new emerging things on the accounting information system. As the main channel for the delivery of accounting talents, accounting education will inevitably be affected by informatization. Although after decades of reform and development, China's accounting education has made great achievements, and it has sent a large number of accounting talents to the society, but there are still many problems, especially in the knowledge transfer and capacity train [1]. Therefore, it is important to clarify the problems existing in the accounting talent training mode of higher vocational colleges under the background of information, and propose targeted improvement and optimization suggestions, which is of great significance to the in-depth integration of information and accounting education and the training of accounting talents needed by the society.

\section{Problems in Training Mode of Accounting Talents under the Background of Informatization}

The core of accounting education is to lay the foundation for the students' lifelong development. However, the current goal of accounting talent training in higher vocational colleges is to cultivate the application of accounting computerized application talents, and over-emphasize the accounting processing, measurement, recording and reporting of accounting information. The training of nontechnical ability is relatively insufficient. This has led to the poor ability of the accounting talents to connect with the actual theory, and does not know how to use these generated information to solve increasingly complex management problems.

The current problems in the content of accounting majors in higher vocational colleges are mainly reflected in the lack of information content. Management information systems, business operations sandbox simulation, computer auditing, internal control and other courses are less open in the accounting profession of higher vocational colleges. Generally, there is only one course of accounting informatization, which mainly teaches the process of using computer software for accounting processing. The accounting graduates thus cultivated cannot meet the actual needs in terms of knowledge structure, accounting ability and other professional abilities. In addition, 
practical teaching has fewer gates and a single model. Most of them are basic and accounting software training after the end of a course, lacking management training such as comprehensive training and accounting analysis.

At present, accounting teaching is still based on the traditional teaching method. Students can only rely on rote memorization to remember the corresponding knowledge points, lack of deep understanding of knowledge points, and can't integrate information into accounting practice. Such teaching methods cannot mobilize the enthusiasm and enthusiasm of students. Innovative teaching methods such as case teaching, role simulation, self-study and instructional teaching can cultivate students' ability of communication, analysis, cooperation and practice, but the implementation effect in teaching is not ideal. At the same time, the degree of utilization of information technology in accounting teaching is not high, and the role of technology such as network and multimedia in teaching is not fully utilized.

First of all, the assessment method is relatively simple. The assignment plus examination is still the main assessment method for the examination of the accounting students' learning effect, and most of them are objective questions. They rarely reflect the assessment of the comprehensive quality of students' theoretical connection with practical ability and analytical ability. Secondly, the lack of adaptation to information technology, the examinations are basically paper-based papers. The current accounting junior and middle-level professional title examinations and CPA exams are all in the form of online answering, which saves resources and improves efficiency, and can effectively prevent students from copying.

\section{Optimization of Accounting Talent Training Mode in the Informatization}

Under the background of information technology, checking accountants can no longer meet the needs of enterprises, and non-checking capabilities are increasingly valued by enterprises. Enterprises need high-quality, management-oriented accounting talents. In the context of information, accounting talents need to have both accounting knowledge and economics, management knowledge, and comprehensive ability to collect and analyze information, communication, cooperation, innovation, access to new knowledge, and response and control of information. They should be able to use computers to solve accounting operations and provide realtime and effective information for management decisions [2]. Therefore, the goal of accounting talent training in higher vocational colleges should be oriented to the cultivation of composite application accounting talents with solid modern accounting theory knowledge, proficiency in modern information technology, and comprehensive ability of lifelong learning and innovation. At the same time, higher vocational colleges should establish information communication channels with demanders and accounting graduates, and obtain relevant information on the professional performance and growth trajectory of accounting graduates in various organizations, and integrate them into capacity structure evaluation and demand. Combined with the characteristics of regional economic development, the accounting teaching objectives are adjusted in a timely and reasonable manner.

At present, there are fewer accounting information courses in the accounting teaching curriculum system of higher vocational colleges, and there is a lack of training for students' information literacy. Through the establishment of accounting information technology synthesis, the operation and use of general accounting software, XBRL theory and application, VBSE accounting simulation training system, Access database, database application system development, electronic data processing and development, Excel application in accounting, etc. To enable students to master the basic knowledge of computer hardware, software and computer system analysis and design, and to use the office software and information tools to complete financial processing, analysis and system maintenance processing. Cultivate accounting students to use information technology to complete the awareness and ability of accounting work, exercise their data acquisition, organization and analysis capabilities, and provide effective decision-making information services for business managers.

Basic accounting and so on are aimed at cultivating students' accounting ability. This is the basic 
goal that accounting education must achieve. At the same time, enterprises in the information environment pay more attention to the value of information and the prevention of risks. Internal control, internal audit, risk and strategic management departments are receiving more and more attention. Therefore, we should pay attention to the teaching of the basic knowledge of accounting majors. At the same time, interdisciplinary courses such as finance, e-commerce, and marketing can be used as elective courses to help students master more knowledge background and contribute to the formation of efficient and reasonable professional judgment.

As a practical teaching of accounting talents' non-accounting ability training, it is urgent to change the status quo of less subject, less class, and single mode. In addition to the basic accounting software training, it should also increase the practice of financial information simulation practice, comprehensive simulation experiment, computer audit, sand table simulation of enterprise management. For example, the ERP sandbox simulation enterprise management system builds the internal and external environment for the simulation enterprise for the accounting experiment teaching, and allows the students to experience and learn in the most intuitive way with the complicated abstract financial and business management theory. Students will express all kinds of resources, plans and management information in the form of accounting information in a timely and effective manner in a series of activities such as market analysis, strategic system, financial management and cash flow management.

Higher vocational school accounting theory teaching should make full use of advanced information technology such as Internet of Things, cloud computing, big data, financial shared service platform, so that students can understand how to apply accounting knowledge to practical work under the processing of computer and other information technology, not only can Inspire learning initiative, and also truly cultivate the knowledge and ability. For example, when teaching the theory of financial analysis methods, take the latest financial report of a listed company as an example, use EXCEL to establish a financial model, and use XBRL financial reporting tools to analyze the financial report of listed companies [3].

Innovative teaching methods such as case teaching, group discussion, instructional teaching, and role simulation are important ways to develop students' non-accounting ability. The development of information provides more convenient conditions for the implementation of innovative teaching methods, so we should give full play to the advantages of information technology. Taking the case teaching method as an example, the information requirements are embodied in the case design, and the students' data collection ability, analysis ability, expression ability and cooperation ability are exercised, and the subjective initiative of the students is fully exerted. For example, taking the current financial hotspot as a case, or allowing students to freely choose the case related to the course content, let the students use the network to collect information related to the case, and then express their understanding and opinions on the case and knowledge points in the classroom. The teacher asks questions and gives comments and extensions based on the student's analysis.

In the information environment, accounting teaching should aim at cultivating students' knowledge ability, accounting ability and non-accounting ability. The examination content should reflect the comprehensive investigation of the above contents. Subjects that require a solid foundation in theoretical foundations, such as basic accounting courses, can be assessed on the basis of objective questions, examining students' mastery of theoretical connotations and the ability to connect theory with practice. For analytical and comprehensive courses, such as financial report analysis, risk and strategic management, subjective questions should be assessed. The content of the exam should be derived from the textbook and not tied to the textbook, combined with the latest industry case design to examine the non-accounting ability of students' analytical ability and judgment ability.

The current accounting junior and middle-level professional title examinations and CPA exams are all in the form of online answering questions. Accounting education should follow the form of the times and increase the online evaluation system, which saves resources and improves efficiency, and can effectively prevent students from copying. 


\section{Conclusion}

Under the background of information, the accounting professionals required by the society have undergone qualitative changes in terms of knowledge and ability, and it is inevitable to change the corresponding talent training mode. At the macro level, it is necessary to scientifically position the accounting talent training objectives. At the micro level, it is necessary to optimize the accounting teaching system. Through the consideration of accounting talent information literacy and the application of accounting teaching information technology to adapt to the needs of information development.

\section{References}

[1] Liang Yaling. Research on Accounting Information Teaching Research [J]. Communication of Finance and Accounting, 2017, (31): 53-56.

[2] Ding Shuqin. Research on the Cultivation of Compound Accounting Information Talents in Colleges and Universities [J]. Friends of Accounting, 2010, (5): 114-115.

[3] Tian Jiuling. Discussion on Accounting Simulation Practice Teaching in Information Environment [J]. Communication of Finance and Accounting, 2013, (6):23-24. 